\title{
REMEDIASI MISKONSEPSI KINEMATIKA GERAK LURUS DENGAN PENDEKATAN STAD
}

\author{
Yaspin Yolanda \\ Pendidikan Fisika STKIP PGRI LUBUKLINGGAU \\ yaspinyolanda@stkippgri-lubuklinggau.ac.id
}

Submit, 21-12-2017 Accepted, 29-12-2017 Publish, 29-12-2017

\begin{abstract}
: this study aims to (1) find out the percentage change of kinematic misconscope of motion straight after remediation, (2) Student Response in remediation implementation with cooperative learning approach Student Team Achievement Division (STAD) class X MAN 1 Model Lubuklinggau Lesson Year 2015/2016. Subjects were 21 students based on purposive sampling technique based on previous research conducted by Novitasri, N.M (2016). The research method used is descriptive qualitative. Technique of data collecting done by triangulation that is diagnosis understanding student concept, interview and questionnaire of student response in learning. Remediation of misconceptions with cooperative learning approach Student Team Achievement Divisions (STAD) showed that from 17 items tested before remediation mean misconception percentage 80,11\% (former researcher) and after remediation to 37,53\% $42.58 \%$. Student response after remediation using STAD learning is very good.
\end{abstract}

Keyword: miskonsepsi, remediasi, STAD

\begin{abstract}
Abstrak: Penelitian ini bertujuan (1) mengetahui perubahan persentase miskonsepsi kinematika gerak lurus setelah remediasi, (2) Responsi siswa dalam pelaksanaan remediasidengan pendekatan pembelajaran kooperatif Student Team Achievement Divisions (STAD) kelas X MAN 1 Model Lubuklinggau Tahun Pelajaran 2015/2016.Subjek penelitian berjumlah 21 siswa berdasarkan teknik purposive samplingberdasarkan penelitian terdahulu yang dilakukan oleh Novitasri, N.M (2016). Metode penelitian yang digunakan adalah deskriptif kualitatif. Teknik pengumpulan data dilakukan dengan cara triangulasi yakni diagnosis pemahaman konsep siswa, wawancara dan angket respon siswa dalam pembelajaran. Remediasi miskonsepsi dengan pendekatanpembelajaran kooperatif Student Team Achievement Divisions $(S T A D)$ menunjukan bahwa dari 17 butir soal yang diujikan sebelum remediasi rata-rata persentase yang miskonsepsi sebesar 80,11\% (peneliti terdahulu) dan setelah remediasi menjadi 37,53\% sehingga terjadi penurunan sebesar $42,58 \%$.
\end{abstract}

Kata Kunci: miskonsepsi, remediasi, STAD

\section{PENDAHULUAN}

Miskonsepsidalam pembelajaran fisika sering terjadi sehingga menjadi penghambat siswa dalam memahami dan menghubungkan konsep yang akan dipelajari, sehingga menimbulkan kesalahan, kesulitan dalam belajar fisika. Maka miskonsepsi siswa harus diatasi. Sebelum mengatasi miskonsepsi siswa, diperlukan identifikasi untuk mengetahui tingkat miskonsepsi yang dialami siswa. Suparno (2005) menjelaskan bahwa ada beberapa cara yang digunakan untuk mengidentifikasi miskonsepsi siswa diantaranya tes multiple choice dengan reasoning terbuka dan wawancara. Pada tes multiple choice dengan reasoning terbuka, siswa harus memberikan alasan, argumen yang tepat dalam menjawab soal. Setelah mendeteksi miskonsepsi, artinya kita harus mampu membedakan antara siswa yang memahami konsep, tidak tahu konsep, dan siswa yang miskonsepi berdasarkan tingkat keyakinan yang dikenal dengan istilah CRI (Certainly of Response Index).

Berdasarkan hasil penelitian terdahulu yang dilakukan (Novitasari, N.M, 2016) tentang Analisis Miskonsepsi Fisika Siswa Kelas X MAN 1 (Model) Lubuklinggau Tahun Pelajaran 2015/2016 pada Pokok Bahasan Kinematika Gerak Lurus menggunakan tes multiple choice dengan reasoning terbuka dilengkapi 
Certainty of Response Index (CRI) bahwa dari 17 soal instrumen yang di ujikan kepada 21 subjek penelitian terdapat siswa mengalami miskonsepsi pada setiap butir soal namun pada soal nomor 5 dengan indikator soal "siswa mampu menghitung jarak yang ditempuh oleh seseorang melalui gambar yang diberikan" dan soal nomor 7 dengan indikator soal "siswa dapat memahami gerak apa yang terjadi ketika kendaraan bermotor bergerak dengan kecepatan tetap" siswa lebih banyak menguasai konsep dengan baik daripada siswa yang mengalami miskonsepsi, dan tidak tahu konsep. Hasil rekapitulasi rata-rata persentase yaitu rata-rata siswa kategori tahu konsep sebesar $19,89 \%$, rata-rata persentase siswa yang mengalami miskonsepsi sebesar 80,11\%. Sehingga rata-rata persentase siswa yang mengalami miskonsepsi lebih besar daripada siswa yang tahu konsep.

Untuk mengatasi miskonsepsi siswa tersebut dibutuhkan model pembelajaran berkelompok, sehingga miskonsepsi setiap siswa bisa terukur satu per satu berdasarkan pengelompokkan masalah. Model pembelajaranStudent Team Achievement Divisions (STAD)sangat cocok kami pilih berdasarkan analisa sintak pembelajaran agar tujuan dari penelitian ini tercapai. (Rusman,2011) menyatakan "model pembelajaran Student Team Achievement Divisions (STAD) merupakan variasi pembelajaran kooperatif yang paling banyak diteliti, gagasan utama di belakang STAD adalah memacu siswa agar saling mendorong dan membantu satu sama lain untuk menguasai pengetahuan, memecahkan kasus berdasarkan tingkat pemahaman siswa.

Berdasarkan permasalahan diatas, untuk meminimalisir miskonsepsi fisika maka penulis ingin melanjutkan penelitian terdahulu untuk ditindaklanjuti, yang berjudul "Remediasi Miskonsepsi Kinematika Gerak Lurus Dengan Pendekatan Kooperatif Tipe Student Team Achievement Divisions (STAD).

\section{LANDASAN TEORI}

\section{Gambaran Awal Miskonsepsi Siswa}

(Suparno, 2013) mendefinisikan bahwa miskonsepsi atau salah konsep menunjuk pada suatu konsep yang tidak sesuai dengan pengertian ilmiah atau pengertian yang diterima para pakar dalam bidang itu. miskonsepsi merupakan suatu konsep yang tidak sesuai dengan konsep para ilmuan.

Berdasarkan hasil Penelitian terdahulu yang dilakukan (Novitasari, 2016) tentang Miskonsepsi Kinematika Gerak Lurus siswa kelas X MAN 1 Model Lubuklinggau menggunakan 17 soal tes diagnosis multiple choisereasoning terbuka yang diberikan siswa pada tiap butir soal tes multiple choice dengan reasoning terbuka dilengkapi certainty of response index (CRI), siswa cenderung mengalami miskonsepsi pada konsep dapat diambil kesimpulan, seperti yang dijabarkan dalam tabel 1.

Tabel 1. Dokumentasi Miskonsepsi Siswa Pada Konsep Fisika

\begin{tabular}{ccc}
\hline $\begin{array}{c}\text { Konsep } \\
\text { Kinematika } \\
\text { Gerak Lurus }\end{array}$ & $\begin{array}{c}\text { Nomor } \\
\text { Soal }\end{array}$ & Miskonsepsi siswa \\
\hline Jarak dan & $\begin{array}{c}\text { Siswa beranggapan bahwa jarak dan perpindahan sama, namun ada } \\
\text { sebagian siswa yang mengatakan jarak dan perpindahan berbeda tetapi } \\
\text { mereka tidak tahu apa perbedaan dari jarak dan perpindahan tersebut. }\end{array}$ \\
Perpindahan & dan 6 &
\end{tabular}




\begin{tabular}{|c|c|c|}
\hline $\begin{array}{l}\text { Konsep } \\
\text { Kinematika } \\
\text { Gerak Lurus }\end{array}$ & $\begin{array}{l}\text { Nomor } \\
\text { Soal }\end{array}$ & Miskonsepsi siswa \\
\hline $\begin{array}{l}\text { Kelajuan dan } \\
\text { Kecepatan }\end{array}$ & 3 dan 4 & $\begin{array}{l}\text { a. Siswa juga tidak dapat membedakan antara besaran kelajuan dan } \\
\text { kecepatan. } \\
\text { b. Soal nomor 4, siswa beranggapan nilai yang bergerak pada } \\
\text { speedometer merupakan nilai kecepatan, alasan siswa bahwa } \\
\text { kecepatan ialah jarak/waktu dan satuannya } \mathrm{m} / \mathrm{s} \text { atau } \mathrm{km} / \mathrm{jam} \text {. }\end{array}$ \\
\hline $\begin{array}{c}\text { Gerak Lurus } \\
\text { Beraturan (GLB) }\end{array}$ & 7 dan 8 & $\begin{array}{l}\text { a. siswa belum mengetahui grafik hubungan kecepatan } \mathrm{v} \text { terhadap } \\
\text { fungsi waktu t pada konsep gerak lurus beraturan. } \\
\text { b. Siswa beranggapan bahwa grafik yang lurus maka kelajuannya } \\
\text { tetap. }\end{array}$ \\
\hline $\begin{array}{l}\text { Gerak Lurus } \\
\text { Berubah } \\
\text { Beraturan } \\
\text { (GLBB) }\end{array}$ & $\begin{array}{l}9,10 \\
\text { dan } 11\end{array}$ & $\begin{array}{l}\text { a. Siswa beranggapan bahwa konsep rumus gerak lurus berubah } \\
\text { beraturan (GLBB) sama dengan konsep rumus gerak lurus } \\
\text { beraturan (GLB). } \\
\text { b. Siswa tidak memperhatikan adanya kecepatan awal pada gerak } \\
\text { lurus berubah beraturan dan menganggap bahwa pada gerak lurus } \\
\text { berubah beraturan hanya memiliki percepatan dan tidak } \\
\text { memperhatikan adanya percepatan negatif atau perlambatan. }\end{array}$ \\
\hline
\end{tabular}

\begin{tabular}{ccl}
\hline Gerak Jatuh & 12,15, & $\begin{array}{l}\text { siswa beranggapan bahwa konsep gerak jatuh bebas dipengaruhi oleh } \\
\text { kecepatan awal tertentu dan kecepatannya selalu konstan dari awal } \\
\text { Bebas (GJB) }\end{array}$ \\
$\begin{array}{ccl}16, \text { dan } \\
17\end{array}$ & $\begin{array}{l}\text { singga akhir. } \\
\text { maksimum kecepatan benda bertambah karena benda akan jatuh lagi ke }\end{array}$ \\
Gerak Vertikal & 13 dan & $\begin{array}{l}\text { mangan bahwa pada saat benda mencapai ketinggian } \\
\text { lantai. }\end{array}$
\end{tabular}

\section{Penyebab Miskonsepsi}

(Yolanda.Y, 2016) menjelaskan bahwa penyebab miskonsepsi pada siswa ialah sebagai berikut (1) Siswa, ketika siswa mencerna dan mendapat simpulan pengetahuan tanpa pembenaran konsep yang benar dari guru. (2) Guru/Pengajar, guru yang tidak menguasai konsep cenderung mengajarkan konsep yang salah. (3) Buku Teks, komunikasi bahasa yang sulit dipahami dalam buku cenderung menimbulkan salah tafsir dari pembaca, bagi pembaca khususnya siswa yang sedang belajar dapat juga menumbuhkan miskonsepsi karena

Sumber: (Novitasari, 2016)

mereka menangkap sebagian atau bahkan tidak mengerti sama sekali.(4) Konteks, Konteks terdiri dari pengalaman siswa, bahasa sehari-hari yang berbeda, teman lain atau teman diskusi yang salah, penjelasan orang tua/orang lain yang keliru, yang kesemuanya itu dapat menyebabkan miskonsepsi.

Berdasarkan hasil wawancara peneliti terdahulu maka secara umum dapat disimpulkan penyebab siswa mengalami miskonsepsi siswa kelas $\mathrm{X}$ MAN 1 Model Lubuklinggau dapat

Tabel 2. Dokumentasi Penyebab miskonsepsi siswa kelas X MAN 1 Model Lubuklinggau berdasarkan hasil wawancara Peneliti terdahulu

\begin{tabular}{lll}
\hline \multicolumn{1}{c}{ Sebab Utama } & & \multicolumn{1}{c}{ Sebab Khusus } \\
\hline Siswa & 1. & Fisika pelajaran yang paling banyak rumusan/hitungan. \\
& 2. & Siswa masih mengalami kesulitan dalam aljabar yang digunakan dalam \\
& pembahasan soal fisika dan kesulitan dalam menterjemahkan grafik. \\
& 3. & Masih banyaknya kesalahan siswa dalam mengkonversi satuan, kesalahan \\
\hline
\end{tabular}




\begin{tabular}{|c|c|}
\hline & $\begin{array}{l}\text { strategi, kesalahan menuliskan simbol besaran dan kesalahan konsep, } \\
\text { 4. Kurangnya percaya diri siswa untuk bertanya kepada guru } \\
\text { 5. Reasoning siswa yang salah disebabkan oleh miskonsepsi, tidak pahamnya } \\
\text { siswa mengenai materi fisika }\end{array}$ \\
\hline Buku teks & $\begin{array}{l}\text { 1. Sajian kurang menarik minat siswa untuk membaca. } \\
\text { 2. Struktur bahasa dan deskripsi materi terlalu panjang sehingga sulit untuk } \\
\text { menarik inferensi } \\
\text { 3. Pembahasan contoh soal terlalu sedikit, dan langsung pada hasil jawaban, } \\
\text { belum menunjukkan proses membimbing siswa (inkuiri). } \\
\text { 4. Belum bisa mengukur keterampilan proses sains siswa. } \\
\text { 5. Siswa belum bisa memahami cara membaca grafik dan gambar yang } \\
\text { digunakan pada buku. }\end{array}$ \\
\hline Konteks & $\begin{array}{l}\text { Belum kontekstual dan siswa belum bisa memahami manfaat mempelajari } \\
\text { kinematika gerak lurus dalam kehidupan sehari-hari. }\end{array}$ \\
\hline Sumber belajar & Keterbatan Buku teks hanya menggunakan LKS \\
\hline
\end{tabular}

\section{Remediasi sebagai Solusi untuk Mengatasi Miskonsepi}

(Astuti. M, 2014)mengatakan bahwa Pembelajaran remedial berjalan efektif jika pembelajaran remedial dilakukan dengan media atau model yang berbeda dari pembelajaran sebelumnya, sehingga membantu siswa memenuhi ketuntasan KKM.(Yolanda. Y, 2016) menjelaskan secara garis besar langkah yang digunakankan untuk membantu mengatasi miskonsepsi adalah remediasi yakni (1) Mencari atau mengungkap miskonsepsi yang dilakukan siswa; (2) Mencoba menemukan penyebab miskonsepsi tersebut dan (3) Mencari perlakuan yang dengan cara meremediasi kembali materi.Pembelajaran remedial merupakan pemberian perlakuan khusus terhadap peserta didik yang mengalami hambatan dalam kegiatan belajarnya. Hambatan yang terjadi yakni kurangnya pengetahuan dan keterampilan prasyarat atau lambat dalam mecapai kompetensi.

Beberapa prinsip yang perlu diperhatikan dalam pembelajaran remedial yakni (1) Pembelajaran remedial hendaknya mampu mengukur dan menjadi solusi bagi kesulitan siswa, kesalahan siswa, miskonsepsi siswa dalam memahami materi yang telah diuji. (2) Pembelajaran remedial harus bisa meningkatkan pemahaman konsep siswa secara individu maupun kelompok peserta didik. (3) Metode Pembelajaran dan
Penilaiansesuai dengan keragaman peserta didik sehingga siswa efektivitasnya bisa terwujud. (4)Pelaksanaan Pembelajaran Remedial pada hakikatnya adalah pembelajaran khusus bagi peserta didik yang belum mencapai kriteria minimum ketuntasan hasil belajar yang meliputi dua langkah pokok, yaitu pertama mendiagnosis kesulitan belajar siswa apakah berat, sedang dan ringan, dan kedua memberikan perlakuan (treatment) pembelajaran remedial antara lain: tes prasyarat dengan soal yang sama, dan soal terbaru tanpa mengubah indikator soal, mendiagnosis langsung kesulitan,kesalahan, miskonsepsi yang terjadi pada siswa. Ketiga, evaluasi dalam mengukur tingkat pemahaman siswa.

\section{Bentuk Pelaksanaan Pembelajaran Remedial}

Setelah diketahui kesulitan belajar yang dihadapi peserta didik, langkah berikutnya adalah memberikan perlakuan berupa pembelajaran remedial. Bentukbentuk pelaksanaan pembelajaran remedial antara lain (1) Pembelajaran tutor sebaya, (2) menggunakan model pembelajaran kooperatif dan pembelajaran langsung. (3) Pemberian bimbingan secara khusus. Dan (4) Pemberian tugas-tugas latihan secara maksimal dan pengulangan untuk 
membantu menguasai kompetensi yang ditetapkan.

\section{Pembelajaran Kooperatif Tipe STAD} (Rusman, 2011) menyebutkan bahwa pembelajaran kooperatif tipe
Student Team Achievement Divisions (STAD) merupakan pembelajaran berkelompok untuk membangun kerja sama tim untuk menguasai keterampilan yang diajarkan guru. seperti dijabarkan di tabel3.

Tabel 3. Sintak Model Pembelajaran STAD

\begin{tabular}{lll}
\hline \multicolumn{1}{c}{ Tahapan } & \multicolumn{2}{c}{ Kegiatan Guru } \\
\hline $\begin{array}{l}\text { Fase 1 } \\
\text { (Menyampaikan } \\
\text { tujuan pembelajaran) }\end{array}$ & 1. & $\begin{array}{l}\text { Guru menyampaikan Indikator materi yang ingin dicapai pada } \\
\text { pembelajaran tersebut dan memotivasi siswa untuk belajar }\end{array}$ \\
& &
\end{tabular}

\begin{tabular}{|c|c|}
\hline $\begin{array}{l}\text { Fase } 2 \\
\text { (Pembentukan } \\
\text { kelompok) }\end{array}$ & $\begin{array}{l}\text { 2. Guru membagi siswa menjadi } 4 \text { kelompok yang terdiri dari 5-6 orang } \\
\text { peserta didik yang memprioritas tingkat kemampuan siswa tinggi, } \\
\text { sedang dan rendah. }\end{array}$ \\
\hline $\begin{array}{l}\text { Fase } 3 \\
\text { (Menyajikan materi) }\end{array}$ & $\begin{array}{l}\text { 3. Setiap kelompok diberi handout pembelajaran berbeda berdasarkan } \\
\text { materi GLB, GLBB, GVA/GVB dan GJB. } \\
\text { 4. Guru memberikan waktu kepada siswa untuk membaca handout yang } \\
\text { dibagikan } \\
\text { 5. Guru menjelaskan materi tentang kinematika gerak lurus. } \\
\text { 6. Guru memberikan contoh soal tentang materi GLB, GLBB, GVA/GVB } \\
\text { dan GJB }\end{array}$ \\
\hline $\begin{array}{l}\text { Fase } 4 \\
\text { (Pemberian soal dan } \\
\text { persentasi kelompok) }\end{array}$ & $\begin{array}{l}\text { 7. Guru memberikan soal untuk dibahas dalam kelompok tentang materi } \\
\text { GLB, GLBB, GVA/GVB dan GJB. } \\
\text { 8. Siswa yang berkemampuan tinggi membimbing siswa yang kemampuan } \\
\text { rendah dalam kelompok dengan pengawasan guru. } \\
\text { 9. Masing-masing kelompok mempersentasikan di depan kelas dengan cara } \\
\text { membahas soal-soal secara bergiliran. } \\
\text { 10. Bagi siswa yang belum memahami materi maka peran guru untuk } \\
\text { membimbing dan memberikan penjelasan. } \\
\text { 11. Gurumembimbing jalannya diskusi dan memberikan penguatan terhadap } \\
\text { jawaban siswa. }\end{array}$ \\
\hline $\begin{array}{l}\text { Fase } 5 \\
\text { Evaluasi }\end{array}$ & $\begin{array}{l}\text { 12. Guru memberikan soal diagnosis miskonsepsi terdahulu yakni multiple } \\
\text { choise dengan reasoning terbuka tentang Kinematika Gerak Lurus } \\
\text { dengan sub materi GLB, GLBB, GVA/GVB dan GJB. } \\
\text { 13. Guru menganalisisdan mendiagnosis jawaban siswa atas ketercapaian } \\
\text { pemahaman konsep individu siswa di semuakelompok. }\end{array}$ \\
\hline $\begin{array}{l}\text { Fase } 6 \\
\text { (Penghargaan) }\end{array}$ & $\begin{array}{l}\text { 14. Setiap jawaban dari pembahasan soal di depan kelas memiliki konsep } \\
\text { benar maka diberi nilai } 100 \text {. Bagi jawaban kurang tepat nilai } 50 \text {. Dan } \\
\text { jawaban salah } 0 \text { untuk tiap butir soal. } \\
\text { 15. Guru memberikan penilaian kelompok untuk menentukan juara1,2 dan } 3 \\
\text { berdasarkannilai yang terkumpul dari membahas soal dengan benar } \\
\text { ketika persentasi. }\end{array}$ \\
\hline
\end{tabular}

\section{METODE PENELITIAN}

Penelitian dilaksanakan dari 25 Juli s.d 2 agustus 2016. Metode penelitian deskriptifkualitatif. Subjek penelitian kelas X MAN 1 Model Lubuklinggau yang diambil dari sampel penelitian terdahulu yang berjumlah 21 siswa. Teknik pengumpulan data dilakukan dengan cara triangulasi yakni dokumentasi hasil tes, wawancara dan angket.

\section{HASIL DAN PEMBAHASAN}

Berdasarkan hasil analisis jawaban siswa dalam menyelesaikan tes diagnosis 
miskonsepsi Kinematika Gerak Lurus dapat dilihat pada tabel 4.

Tabel 4. Rekapitulasi Ketuntasan Siswa pada Materi Kinematika Gerak Lurus

\begin{tabular}{|c|c|}
\hline Butir & Hasil Remediasi Miskonsepsi siswa \\
\hline \multicolumn{2}{|c|}{ Jarak dan Perpindahan } \\
\hline Soal 1 & $\begin{array}{l}\text { 1. Terdapat } 18 \text { Siswa dapat menganalisis apa yang terjadi setelah seseorang melakukan } \\
\text { perjalanan dari posisi A-B-C-D dan kembali lagi ke posisi C. } \\
\text { Perhatikan gambar berikut: }\end{array}$ \\
\hline
\end{tabular}

2. ı eruapat 15 siswa aapat menemukan apa kesamaan yang terjauı úua orang anak ketika dua orang anak berada pada jarak (s) dan pada saat yang sama keduanya saling mendekat lalu di tengah jalan mereka berpapasan.

Soal 2 Terdapat 19 siswa dapat menjelaskan perubahan posisi seseorang dari A ke B (ke kanan) atau dari B ke A (ke kiri).

$\begin{array}{ll}\text { Soal 5 } & \text { Terdapat } 17 \text { Siswa mampu menghitung jarak yang ditempuh_el sesedrang melalui } \\ \text { gambar yang diberikan. }\end{array}$

\section{Gerak Lurus Beraturan (GLB)}

Soal 7 Terdapat 18 siswa dapat memahami gerak apa yang terjadi ketika kendaraan bermotor bergerak dengan kecepatan tetap.

\begin{tabular}{ll}
\hline Soal 8 & $\begin{array}{l}\text { Terdapat } 19 \text { siswa dapat menginterpretasi grafik pada gerak lurus dengan kecepatan } \\
\text { konstan }\end{array}$ \\
\hline Gerak Lurus Berubah Beraturan (GLBB) & Terdapat 17 siswa dapat menghitung jarak tempuh mobil sejak direm sampai \\
\hline Soal 9 & $\begin{array}{l}\text { berhenti.Ketika sebuah mobil bergerak dengan kecepatan tertentu, mobil tersebut } \\
\text { menghindari tabrakan, mobil direm sampai berhenti dalam waktu beberapa sekon. }\end{array}$ \\
\hline Soal 10 & \begin{tabular}{l} 
Terdapat 16 siswa dapat menganalisis dan menjelaskan apa yang terjadi dengan anak \\
kucing pada saat seorang anak mengendarai sepeda dengan kecepatan tertentu, tiba-tiba ia \\
melihat seekor anak kucing ditengah jalan dengan jarak x. Sepeda direm dengan \\
perlambatan maksimum. \\
Serdapat 21 siswa dapat mengklasifikasikan gambar yang menunjukan mobil sedang \\
bergerak dengan percepatan tetap dengan cara memberikan beberapa gambar pengamatan \\
tetesan oli yang melaju pada jalan lurus. \\
\hline Gerak Jatuh Bebas (GJB) \\
\hline Teal 12 \\
Tijatuhat 21 Siswa dapat menjelaskan bagaimanakah kecepatan awal koin jika sebuah koin
\end{tabular} \\
\hline
\end{tabular}




\begin{tabular}{|c|c|}
\hline Soal 15 & $\begin{array}{l}\text { Terdapat } 19 \text { Siswa dapat menentukan apa yang akan berbanding lurus dengan kecepatan } \\
\text { sebuah benda jatuh bebas. }\end{array}$ \\
\hline Soal 16 & $\begin{array}{l}\text { Terdapat } 18 \text { Siswa dapat mengklasifikasikan karakteristik benda jatuh bebas, sesuai } \\
\text { dengan pernyataan yang benar. }\end{array}$ \\
\hline Soal 17 & $\begin{array}{l}\text { Terdapat } 18 \text { dapat menjelaskan kecepatan benda pada saat menyentuh tanah ditentukan } \\
\text { oleh apa, ketika benda tersebut jatuh dari ketinggian tertentu dan tidak ada faktor lain yang } \\
\text { mempengaruhi. Siswa dapat menjelaskan kecepatan benda pada saat menyentuh tanah } \\
\text { ditentukan oleh apa, ketika benda tersebut jatuh dari ketinggian tertentu dan tidak ada } \\
\text { faktor lain yang mempengaruhi. }\end{array}$ \\
\hline \multicolumn{2}{|c|}{ Gerak Vertikal } \\
\hline Soal 13 & $\begin{array}{l}\text { Terdapat } 17 \text { siswa mampu menganalisisgerakjatuhbebas (GJB) dan gerak vertikal. Yakni } \\
\text { dapat menganalisis kecepatan kedua bola pada saat mencapai ketinggian maksimum ketika } \\
\text { dua buah bola dilemparkan vertikal ke atas. }\end{array}$ \\
\hline Soal 14 & $\begin{array}{l}\text { Terdapat } 18 \text { siswa dapat menganalisis besarnya percepatan bola pada saat mencapai } \\
\text { ketinggian maksimum ketika sebuah bola dilempar vertikal ke atas dengan kecepatan awal } \\
\mathrm{v}_{\mathrm{o}} \text {. }\end{array}$ \\
\hline
\end{tabular}

Berdasarkan hasil angket dan wawancara tentang respon siswa tentang STAD menunjukkan bahwa adanya kompetisi setiap regu untuk menjadi juara, dan sangat membantu siswa dalam mengatasi kesulitan belajar, kesalahan dan miskonsepsi yang selama ini salah, dan siswa lebih berani dalam mengajukan argumen selama diskusi berlangsung. STAD sangat membantu terciptanya pembelajaran

yanginteraktif,menyenangkan, dan memotivasi peserta didikuntuk berpartisipasi aktif dalam pembelajaran(widyanigsih, 2015).Adapun kelemahan pembelajaran STAD sebagian siswa diawal pertemuan belum terbiasa dengan pembelajaran STAD, membutuhkan waktu yang lebih lama untuk siswa sehingga sulit mencapai target kurikulum, membutuhkan waktu yang lebih lama dalam melaksanakan STAD di kelas, Gurupun belum terbiasa dan belum memahami STAD cocok pada pembelajaran Fisika. Sehingga pendapat (Rusman, 2011) tentang kelebihan dan kelemahan STAD benar adanya.

Remediasi miskonsepsi dengan pendekatan pembelajaran kooperatif Student Team Achievement Divisions
(STAD) menunjukan bahwa dari 17 butir soal yang diujikan sebelum remediasi rata-rata persentase yang miskonsepsi sebesar $80,11 \%$ (peneliti terdahulu) dan setelah remediasi menjadi $37,53 \%$ sehingga terjadi penurunan sebesar 42,58\%.Rekapitulasi rata-rata persentase yaitu rata-rata siswa kategori tahu konsep sebesar $62,47 \%$, dan rata-rata persentase siswa yang mengalami miskonsepsi sebesar 37,53\%. Setelah remediasi menggunakan pendekatan STAD diperoleh Rata-rata persentase siswa yang tahu konsep mengalami kenaikan persentase dan menambah keyakinan akan jawaban yang dipilih berdasarkan CRI. Begitupun pemahaman siswa terhadap konsep materi setelah remediasi terjadi ketercapaian dalam pemahaman konsep yang benar seperti pada tabel 5. Beberapa solusi untuk mengatasi miskonsepsi dapat dirangkumkan dalam tabel 6. 
Tabel 6. Pemahaman Konsep setelah Remediasi menggunakan tes diagnosis

\begin{tabular}{ll}
$\begin{array}{c}\text { Konsep Kinematika } \\
\text { Gerak Lurus }\end{array}$ & \multicolumn{1}{c}{ Miskonsepsi siswa } \\
\hline & $\begin{array}{l}\text { Siswa beranggapan bahwa jarak dan } \\
\text { perpindahan sama, namun ada sebagian siswa } \\
\text { yang mengatakan konsep jarak dan perpindahan } \\
\text { Jarak dan Perpindahan } \\
\text { berbeda tetapi mereka tidak tahu apa perbedaan } \\
\text { dari jarak dan perpindahan tersebut. }\end{array}$ \\
\end{tabular}

\section{Setelah Remediasi}

Siswa sudah memahami dan bisa membedakan konsep Jarak dan posisi

dari jarak dan perpindahan tersebut.

\begin{tabular}{|c|c|c|}
\hline $\begin{array}{l}\text { Kelajuan dan } \\
\text { Kecepatan }\end{array}$ & $\begin{array}{l}\text { 1. Siswa juga tidak dapat membedakan antara } \\
\text { kelajuan dan kecepatan. } \\
\text { 2. Soal nomor } 4 \text {, siswa beranggapan nilai yang } \\
\text { bergerak pada speedometer merupakan nilai } \\
\text { kecepatan, alasan siswa bahwa kecepatan } \\
\text { ialah jarak/waktu dan satuannya } \mathrm{m} / \mathrm{s} \text { atau } \\
\mathrm{km} / \text { jam. }\end{array}$ & $\begin{array}{l}\text { Siswa sudah memahami } \\
\text { dan bisa membedakan } \\
\text { konsep Kelajuan dan } \\
\text { Kecepatan }\end{array}$ \\
\hline $\begin{array}{l}\text { Gerak Lurus Beraturan } \\
\text { (GLB) }\end{array}$ & $\begin{array}{l}\text { 1. siswa belum mengetahui grafik hubungan } \mathrm{v} \\
\text { terhadap t pada konsep gerak lurus beraturan. } \\
\text { 2. Siswa beranggapan bahwa grafik yang lurus } \\
\text { maka kelajuannya tetap. }\end{array}$ & $\begin{array}{l}\text { Siswa sudah memahami } \\
\text { bentuk grafik hubungan } \mathrm{v} \\
\text { terhadap } \mathrm{t} \text { dan s terhadap } \mathrm{t} \\
\text { pada konsep GLB. }\end{array}$ \\
\hline $\begin{array}{l}\text { Gerak Lurus Berubah } \\
\text { Beraturan (GLBB) }\end{array}$ & $\begin{array}{l}\text { 1. Siswa beranggapan bahwa konsep rumus } \\
\text { gerak lurus berubah beraturan (GLBB) sama } \\
\text { dengan konsep rumus gerak lurus beraturan } \\
\text { (GLB). } \\
\text { 2. Siswa tidak memperhatikan adanya kecepatan } \\
\text { awal pada gerak lurus berubah beraturan dan } \\
\text { menganggap bahwa pada gerak lurus berubah } \\
\text { beraturan hanya memiliki percepatan dan } \\
\text { tidak memperhatikan adanya percepatan } \\
\text { negatif atau perlambatan. }\end{array}$ & $\begin{array}{l}\text { 1. Siswa sudah bisa } \\
\text { mengindentifikasi } \\
\text { perbeadaan soal GLB } \\
\text { dan GLBB. } \\
\text { 2. Siswa sudah bisa } \\
\text { memahami perbedaan } \\
\text { GLBB yang dipercepat } \\
\text { dan GLBB diperlambat. }\end{array}$ \\
\hline $\begin{array}{c}\text { Gerak Jatuh Bebas } \\
\text { (GJB) }\end{array}$ & $\begin{array}{l}\text { siswa beranggapan bahwa konsep gerak jatuh } \\
\text { bebas dipengaruhi oleh kecepatan awal tertentu } \\
\text { dan kecepatannya selalu konstan dari awal } \\
\text { hingga akhir. }\end{array}$ & $\begin{array}{l}\text { siswa sudah memahami } \\
\text { bahwa } V_{0}=0 \text { pada GJB }\end{array}$ \\
\hline Gerak Vertikal & $\begin{array}{l}\text { siswa beranggapan bahwa pada saat benda } \\
\text { mencapai ketinggian maksimum kecepatan } \\
\text { benda bertambah karena benda akan jatuh lagi } \\
\text { ke lantai }\end{array}$ & $\begin{array}{lr}\text { siswa sudah } & \text { memahami } \\
\text { bahwa pada } & \text { saat benda } \\
\text { mencapai } & \text { ketinggian } \\
\text { maksimum } & \text { kecepatan } \\
\text { benda berkurang karena } \\
\mathrm{V}_{\mathrm{O}=0 \text {. }}\end{array}$ \\
\hline
\end{tabular}

Tabel 6. Kiat-kiat mengatasi miskonsepsi bedasarkan wawancara penulis.

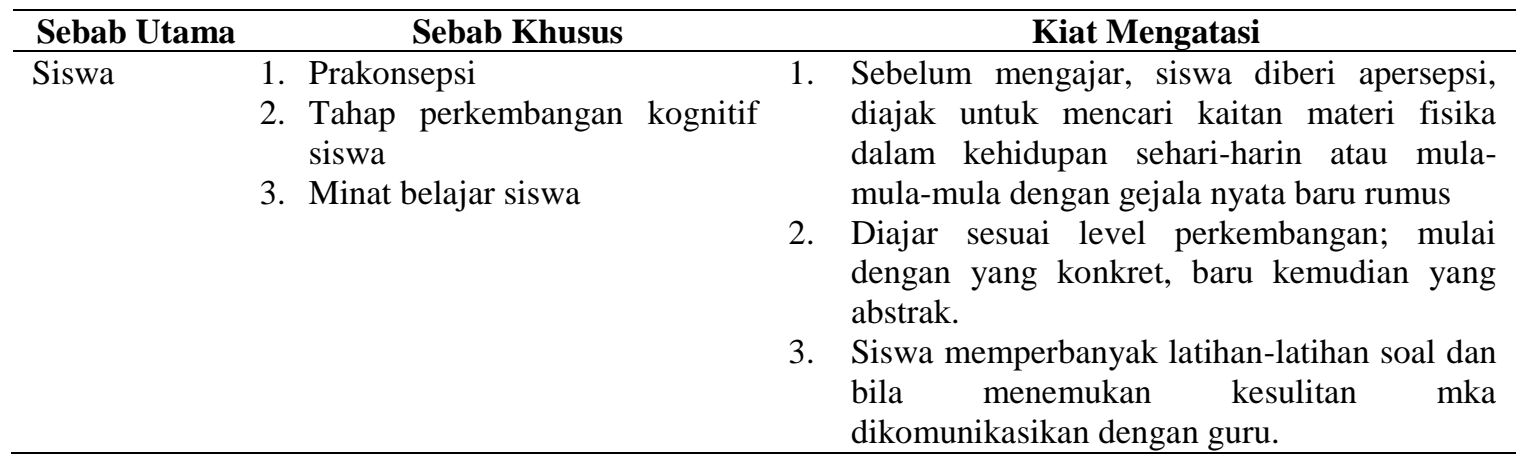




\begin{tabular}{|c|c|c|}
\hline Sebab Utama & Sebab Khusus & Kiat Mengatasi \\
\hline Guru atau & 1. Tidak menguasai bahan & 1. Belajar lagi, lulusan bidang fisika \\
\hline Pengajar & $\begin{array}{l}\text { 2. Tidak memberi waktu siswa } \\
\text { untuk mengungkapkan } \\
\text { gagasan/ide } \\
\text { 3. Relasi guru-siswa masih minim. }\end{array}$ & $\begin{array}{l}\text { 2. Memberi waktu siswa untuk mengungkapkan } \\
\text { gagasan secara lisan atau tertulis } \\
\text { 3. Relasi yang enak, akrab, humor dan tempat } \\
\text { berdiskusi pelajaran. }\end{array}$ \\
\hline
\end{tabular}

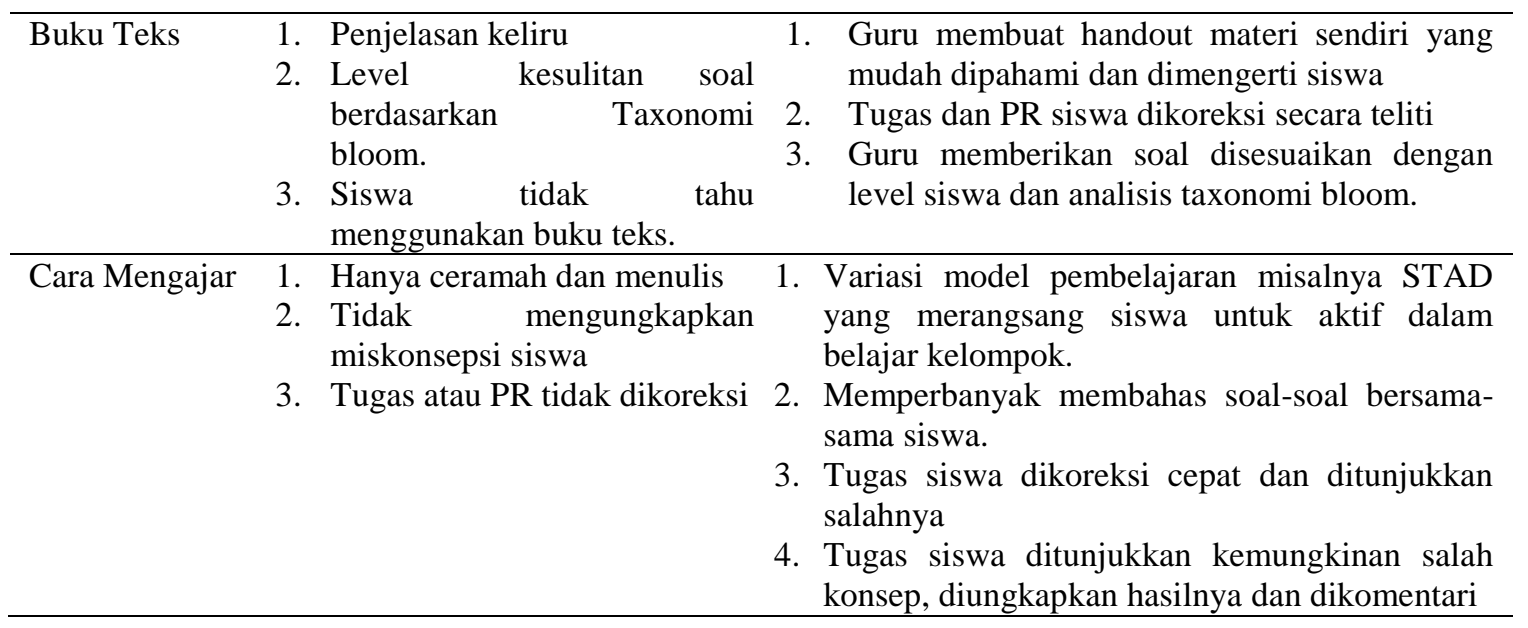

\section{SIMPULAN}

Remediasi miskonsepsi dengan pendekatan pembelajaran kooperatif Student Team Achievement Divisions (STAD) menunjukan bahwa dari 17 butir soal yang diujikan sebelum remediasi rata-rata persentase yang miskonsepsi sebesar $80,11 \%$ (peneliti terdahulu) dan setelah remediasi menjadi $37,53 \%$ sehingga terjadi penurunan sebesar $42,58 \%$. Responsi siswa setelah remediasi menggunakan pembelajaran STAD sangat baik.

\section{DAFTAR PUSTAKA}

Astuti. M (2014), Pemanfaatan Media Tik Tutorial Untuk Remedial Pada Pembelajaran Alat Ukur Di SMP. Jurnal Pendidikan Fisika 2(3) PMIPA FKIP Universitas Lampung.

Novitasari, N.M. (2016). Analisis Miskonsepsi Fisika Siswa Kelas X MAN 1 (Model) Lubuklinggau Tahun Pelajaran 2015/2016 pada Pokok Bahasan Kinematika Gerak Lurus. $\quad$ STKIP PGRI Lubuklinggau. Skripsi tidak diterbitkan. 1, 72-76,

Rusman, (2011). Seri Manajemen Sekolah Bermutu Model - Model Pembelajaran Mengembangkan Profesionalisme Guru. Jakarta: Rajawali Pers. 213

Suparno, Paul. (2014). Metode Penelitian Pendidikan IPA. Yogyakarta: Universitas Sanata Dharma.

Suparno, P. (2013). Miskonsepsi \& Perubahan Konsep dalam Pendidikan Fisika. Jakarta: Grasindo. 4, 30, 55, 123. 
Yolanda. Y (2016).Remediation Of Misconception Momentum And Impulse With5e Learning Cycle Approach. Electronic And Mobile LearningInternational Seminar Proceedings. Postgraduate ProgramUniversitas Negeri Jakarta.

Widyaningsih, (2015). Penerapan Pembelajaran Listrik Dinamis Model Kooperatif Tipe STAD Menggunakan Pendekatan CTL Dengan Integrasi Nilai-Nilai Karakter Terhadap Aktivitas Dan Hasil Belajar Peserta Didik. JuRNAL Pancaran, 4(2),223-234. 